\title{
Hemodynamic gestational adaptation in bitches
}

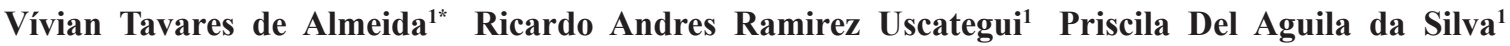 \\ Michele Lopes Avante ${ }^{1}$ Ana Paula Rodrigues Simões ${ }^{1}$ Wilter Ricardo Russiano Vicente ${ }^{1}$
}

'Departamento de Medicina Veterinária Preventiva e Reprodução Animal, Setor de Obstetrícia Veterinária, Faculdade de Ciências Agrárias e Veterinárias (FCAV), Universidade Estadual Paulista (UNESP). Via de Acesso Prof. Dr. Paulo Donato Castellani, Distrito Industrial, s/n., 14884-900, Jaboticabal, SP, Brasil. E-mail: vitalmeida21@hotmail.com. "Corresponding author.

ABSTRACT: Throughout pregnancy, maternal hemodynamic adaptation is needed to ensure proper uterine perfusion and fetal development. When the uteroplacental vascular system is formed, starting with reduced resistance to uterine arterial flow, this results in decreased total vascular resistance, an activation of neuroendocrine vasoactive peptides, an increase in circulating blood and changes in the cardiovascular system morphophysiology to respond to the increasing demands of uterine perfusion. There has been considerable study of hemodynamic adaptation in pregnant women and this assessment has become a diagnostic tool for fatal obstetric disorders. However, in bitches the available information in this regard is limited; therefore a parallel was drawn between other species of animals and women, in order to subsidize the paucity of information about this process and facilitate the understanding of maternal-fetal hemodynamic adaptation in pregnant bitches. This review and literature analysis aimed to discuss morphophysiological cardiovascular adaptations during pregnancy and the possible disorders that can affect this process in pregnant female dogs. Key words: cardiovascular, pregnancy, gestation, morphophysiology, dogs.

\section{Adaptação hemodinâmica gestacional em cadelas}

RESUMO: Durante a gestação, a adaptação hemodinâmica materna é necessária para garantir adequada perfusão uterina e desenvolvimento fetal. A formação de um leito vascular uteroplacentário a partir da redução na resistência ao fluxo da artéria uterina reflete na diminuição da resistência vascular total, ativação de fatores neuroendócrinos vasoativos, aumento do volume de sangue circulante e modificações na morfofisiologia do sistema cardiovascular para responder as demandas crescentes de perfusão uterina. Em mulheres gestantes o estudo da adaptação hemodinâmica encontrase bastante desenvolvido e esta avaliação tem se convertido em uma ferramenta diagnóstica de desordens obstétricas que podem comprometer a relação do binômio materno-fetal. Não obstante, em cadelas a informação disponível a este respeito é limitada e por isso traçou-se um paralelo entre outras espécies de animais e mulheres, de maneira que subsidiassem a carência de informações a este respeito e facilitassem o processo de compreensão da adaptação hemodinâmica materno-fetal em cadelas gestantes. Esta revisão e análise da literatura visa abordar a adaptação morfofisiológica cardiovascular frente à gestação e as possiveis desordens que possam acometer este processo em cães.

Palavras-chave: cardiovascular, gestação, prenhez, morfofisiologia, cães.

\section{INTRODUCTION}

Pregnancy is a physiological process during which the reproductive system is responsible for the maintenance and development of the progeny. This applies from conception until delivery and there are two main phases: embryonic development, or organogenesis, and fetal development (TONIOLLO \& VICENTE, 1993).

For this process proceed correctly, a number of morphological, physiological and biochemical adaptations need to be made in the various organ systems (SARAFANA et al., 2007). Among these, the cardiovascular system responds with hemodynamic changes and, in particular, cardiac output increases as a result of reduced systemic vascular resistance (HAMEED \& SKLANSKY, 2007). These changes play a major role in maintaining uterine perfusion, and they are crucial for fetal development (EGHBALI et al., 2005; BLANCO et al., 2008).

There has been considerable study of these adaptations in women, and it this understanding has proved to be an important tool in obstetric assessment, since there are some complications that are associated with maternal cardiac dysfunction such as thromboembolism, maternal hypertensive disorder and HELLP syndrome, among others. Cardiac disease is the leading non-obstetric cause of maternal death in humans, which underlines the importance of assessing this system during pregnancy (LEWIS \& 
DRIFE, 2004). In dogs, some small-scale studies have already identified and characterized changes in cardiac morphology during pregnancy (ABBOTT, 2010; BLANCO et al., 2011; BLANCO et al., 2012); and although, obstetric complications are less common, there is a high prevalence in certain breeds, the principal cause of which is uterine inertia (STENGEL, 1997; MÜNNICH \& KÜCHENMEISTER, 2009). Little is known of non-obstetric causes of gestational complications, although there are some reports to date that have cited signs of altered maternal cardiovascular function as being predictive of these complications in dogs (BLANCO et al., 2012).

Considering the limited information is available about hemodynamic adaptation during pregnancy in dogs, we aimed to carry out a review and analysis of the literature that will assist us in understanding the nuances of this physiological process and the potential alterations it entails.

\section{Gestational hemodynamics}

Physiological gestation is accompanied by significant adaptations in maternal hemodynamics, both in women and in female dogs (DUVEKOT et al., 1993) and these ensure adequate uterine perfusion and consequently normal fetal development (VALENSISE et al., 2000; BLANCO et al., 2008). Results of the hemodynamic adaptations involving the cardiovascular system in mammals are very similar (DESAI et al., 2004; BLANCO et al., 2011). A pregnancy progresses, formation of the uteroplacental vascular system leads to increased vessel distensibility and compliance (NAUTRUP, 1998; Di SALVO et al., 2006; BLANCO et al., 2009) triggering decreased peripheral vascular resistance (PVR), which results in increased cardiac output (CO) and systolic volume (SV) in pregnancy (BLANCO et al., 2011), as well ventricular remodeling and changes in the renin-angiotensin-aldosterone system (GILSON et al., 1992).

In women, this mechanism of blood vessel compliance is explained by the migration of trophoblasts from the endometrium to the spiral arteries that make up the uteroplacental vascular system. This mechanism leads to structural changes in the arteries, reducing arterial wall muscle, making them bigger and establishing low resistance connections, which culminates in a change in the blood flow to the uterine artery (LIN et al., 1995). This phenomenon brings about decreased PVR and a fall in arterial pressure both in pregnant women and pregnant female dogs (LONGO, 1983).

In addition to these factors, during pregnancy the total volumes of fluid and blood in the body also increase, as a result of fluid and electrolyte retention in the kidneys (GORDON, 2002). The kidneys retain sodium, potassium and calcium, causing increased fluid retention producing a $75 \%$ rise in extracellular fluid volume when compared with nongestational and physiological conditions (PRESTES \& LANDIM-ALVARENGA, 2006). This process stimulates aldosterone production, through the reninangiotensin system (LONGO, 1983). Concomitantly, in the early stages of pregnancy effective renal plasma flow is lower in order to minimize sodium loss, glomerular filtration rate increases in line with the relaxation of the afferent and efferent arterioles of the kidneys, and more fluid is retained than sodium; although the plasma concentration of this electrolyte normalizes the pregnancy progresses (PRESTES \& LANDIM-ALVARENGA, 2006).

These changes result in increased plasma volume from the beginning of pregnancy which gradually falls during the final weeks. The changes in blood volume and renal function trigger a compensatory activity from the maternal cardiovascular system in order to ensure correct maternal-fetal homeostasis (DUVEKOT et al., 1993). Plasma expansion is essential for sufficient uterine perfusion (PRESTES \& LANDIM-ALVARENGA, 2006), these processes having already been demonstrated in other mammals (PHIPPARD et al., 1986; DAVIS et al., 1989).

The maternal heart must respond to the rise in blood volume by boosting cardiac output by up to $40 \%$ in women, $30 \%$ in ewes and $23 \%$ in dogs (BROOKS \& KEIL, 1994; PRESTES \& LANDIMALVARENGA, 2006). Increased intravascular volume influences cardiac preload and afterload as explained by the Frank-Starling law (LONGO, 1983) and consequently improved myocardial performance is required to raise systolic volume and cardiac output (TILLEY \& GOODWIN, 2002). However, the reduction in PVR mentioned previously also contributed to this effect (SPOTSWOOD et al., 2006). As a result of the volume overload and increased demands on the myocardium, which starts with an elongation of the muscle fibers to accommodate the rising blood flow, the left ventricle develops eccentric hypertrophy, a physiological fact that has been observed in women, female dogs and mice (EGHBALI et al., 2005; WILLIAMS et al., 2007; ABOTT, 2010; BLANCO et al., 2012).

In both women and female dogs, whenever the cardiac output remains high, heart rate is also raised (GORDON, 2002; BLANCO et al., 2012a). In the target species, an increase can be identified from the third week of gestation (BLANCO et al., 2011) and 
this continues until lactation (OLSSON et al., 2003). In the literature it is stated that if an increase in heart rate is absent, as well as alterations in the volume or structure of the maternal heart, this can be a predictor of obstetric complications and these findings provides important information for prognosis (OLSSON et al., 2003; BLANCO et al., 2012a). BLANCO et al. (2012) reported that a simultaneous fall in uterine arterial resistance and arterial pressure accompanies a normal gestation in dogs, in contrast to the pathological processes in which this relationship is altered. Under adverse conditions that encourage hypovolemia, pregnant dogs are less able to control arterial pressure than non-pregnant dogs, which may indicate subnormal baroreceptor activity during pregnancy, together with low vasopressin activity (BROOKS \& KEIL, 1994).

In women, maladaptation of the cardiovascular system during pregnancy is correlated with obstetric disorders such as preeclampsia, fetal intrauterine growth restriction, placental abruption and stillbirths (NOVELLI et al., 2003). In this way, the study of maternal cardiovascular adaptations during pregnancy offers important information about maternal-fetal homeostasis and can prove to be a useful tool for the diagnosis and management of gestational complications in dogs (BLANCO et al., 2011).

\section{Echocardiography assessment during gestation}

Cardiac ultrasonography or echocardiography is the standard non-invasive method for the assessment of cardiovascular function and morphology, as well for the diagnosis of cardiovascular disease (THOMAS et al., 1993). As well providing information about diseases, this tool also makes possible to assess the hemodynamic impact on the heart and offers detailed information on wall thickness, patterns of blood flow and some of the indicators of ventricular function (GELENS \& IHLE, 1999).

Two-dimensional, M-mode, color and tissue Doppler echocardiography are all used in pregnant women to assess systolic and diastolic function (VALENSISE et al., 2000; FOK et al., 2006), demonstrating the changes in the shape of the left ventricle that occur during pregnancy to adapt to the vascular load resulting from the gestational process (VALENSISE et al., 2000; DESAI et al., 2004). Few studies have looked at these changes in dogs, and these have related to the reduction in afterload, the increase in systolic function and cardiac hypertrophy during the course of pregnancy (WILLIAMS et al., 2007; BLANCO et al., 2011; BLANCO et al., 2012).

In women, the majority of these changes can be observed from the first trimester of pregnancy (DUVEKOT et al., 1993), while in dogs it is thought that from the thirtieth day of gestation there is an elevation in the shortening fraction (WILLIAMS et al., 2007; BLANCO et al. 2011) that may result from the improvement in systolic function and consequent increased cardiac output (BLANCO et al., 2012), principally due to the greater plasma volume (KITTLESON, 1998). Shortening fraction is directly proportional to the end-systolic dimensions of the left ventricular chamber, which are greater during the period prior to delivery, and reduce gradually as the plasma volume normalizes (ABBOTT, 2010). By the fortieth day, there is an effective increase in systolic volume and output (WILLIAMS et al., 2007) that occurs due to the reduction in total vascular resistance that accompanies the formation of the uteroplacental vascular system and contributes to increased blood supply to the conceptus (SPOTSWOOD et al., 2006; WILLIAMS et al., 2007). During this period, vascular compliance increases to accommodate the greater volume of blood (VALENSISE et al., 2000; BLANCO et al., 2009).

After 50 to 60 days, increases can be observed in end-systolic and end-diastolic left ventricular diameter (LVDs and LVDd), left ventricular free wall dimensions (LVFW) and systolic volume, with heart rate and cardiac output also reaching higher values (WILLIAMS et al., 2007;BLANCO et al., 2011). These structural changes are caused mainly by the volume overload that drives the physiological adaptation of the fibers of the myocardium, evident in the increased internal diameter of the left ventricular chamber and the free wall in systole without increased thickness in diastole, demonstrating hypertrophy to be stable (EGHBALI et al., 2005; WILLIAMS et al., 2007;ABBOT, 2010). Heart rate and cardiac output reach their peak approximately four days before delivery, in order to ensure a sufficient supply of oxygen and nutrients to the fetus until the effective and appropriate length of time has passed for gestation from conception (OLSSON et al., 2003; BLANCO et al., 2011).

Echocardiographic indices, such as left atrial size/aortic diameter ratio (LA/Ao), E-point septal separation (EPSS), aortic amplitude (AA), and left ventricular ejection time (LVET), do not appear to be particularly impacted by the gestational process (ABBOT, 2010; BLANCO et al., 2011). Changes in other flow patterns in pregnant dogs have not been reported in the literature to date, except for the effect of gestational time on transvalvular velocity, studied using Doppler ultrasonography, and which suggests better systolic performance towards the end of gestation (ABOTT, 2010).

Parameters of systolic function in pregnant dogs are well defined and are fundamental to our understanding of maternal-fetal hemodynamics 
(WILLIAMS et al., 2007; ABOTT, 2010; BLANCO et al., 2011; BLANCO et al., 2012). Findings are similar to those seen in women in terms of increased demand with vascular overload (DESAI et al., 2004) and of cardiac hypertrophy (WILLIAMS et al., 2007) as well in other species of mammals (EGHBALI et al., 2005).

In spite of vascular overload bringing about significant adaptations of the heart consisting of remodeling of the chambers and hypertrophy, though these are of a physiological nature and do lead to changes in systolic function in pregnant dogs, diastolic function theoretically remains unchanged (ABBOT, 2010). In the course of the majority of cardiovascular diseases, a failure of myocardial relaxation can be observed, even before any compromised systolic function (ZILE et al., 2002). Studies in humans have shown that over $50 \%$ of patients with congestive heart failure have preserved systolic function and damaged diastolic function (KITZMAN et al., 2001).

The most common method for assessing this function and measuring transmitral flow velocities is by pulsed-wave Doppler echocardiography (MORAN et al., 2002), which shows the pressure gradient between the left atrium and ventricle during diastole. The increase in left atrial preload drives an increase in maximum velocity of both the $E$ wave and A wave of transmitral flow (NISHIMURA, 1993; YAMAMOTO et al., 1996), whereas the increase in peripheral resistance (afterload) leads to a decreased maximum velocity for the $\mathrm{E}$ wave and increases maximum A wave velocity (NISHIMURA, 1993). However, this method does not evaluate the primary events of left ventricular relaxation, instead measuring the impact of diastolic left ventricular alterations, through diastolic flow velocity, which is strongly influenced by the conditions of ventricular load (CHOONG et al., 1987).

In women, an increased maximum E-wave velocity in early pregnancy is compatible with an increase in left atrial preload and left ventricular compliance under normal conditions. At the pregnancy progresses, a decline in E-wave velocity points to a reduction in left ventricular compliance that is due to myocardial hypertrophy and increased peripheral resistance. Yet an increased A-wave reflects the demands on the left atrium to maintain a sufficient pressure gradient to adequately fill the ventricle (YAMAMOTO et al., 1996). Given that preload and afterload are altered during pregnancy (MORAN et al., 2002) the changes in transmitral flow cannot be considered to be direct indicators of diastolic function (FOK et al., 2006).
Another method of assessing diastolic function is tissue Doppler, which is suitable for the evaluation of the primary events of myocardial relaxation since it is relatively independent of preload and for this reason it is considered to be a more accurate tool for this purpose (NAGUEH et al., 1997; SOHN et al., 1997; FOK et al., 2006). In women the indices reflect the changes in left ventricular geometry. Alterations are much more noticeable in the septum than in the lateral wall. There is an increase in measurements relating to systolic function, and in the atrial contribution to diastole, without any evidence of increased filling pressures (BAMFO et al., 2006). In pregnant dogs, we do not found references of this technique application in order to study the assessment of gestational hemodynamics.

\section{CONCLUSION}

Gestation causes significant cardiovascular hemodynamic adaptations, similar to those seen in women. The assessment of these physiological alterations can be a useful tool for diagnosis of hemodynamic disorders during pregnancy and for routine management, mainly in animals that are predisposed to cardiac and obstetric alterations. However, physiological studies are still needed to establish the normal parameters in the species, which will lead to a more accurate understanding of these adaptations and the identification of the possible complications.

\section{ACKNOWLEDGEMENTS}

The authors would like to thank Fundação de Amparo á Pesquisa do Estado de São Paulo (FAPESP) for the financial support to the current research and for postdoctor scholarship support (Processes 2010/16913-7 and 2011/06011-9) and Coordenação de Aperfeiçoamento de Pessoal de Nível Superior (CAPES) for the scholarship granted.

\section{REFERENCES}

ABBOTT, J.A. The effect of pregnancy on echocardiographic variables in healthy bitches. Journal of Veterinary Cardiology, v.12, p.123-128, 2010. Available from: <http://www.ncbi.nlm.nih.gov/pubmed/20615775>. Accessed: Ago. 06, 2016. doi:10.1016/j.jvc.2010.02.001.

BAMFO, J.E.A.K. et al. Reference ranges for tissue doppler measures of maternal systolic and diastolic left ventricular function. Ultrasound in Obstetricsand Gynecology, v.29, p.414-420, 2007. Available from: $<$ http://onlinelibrary.wiley.com/doi/10.1002/uog.3966/full>. Accessed: Ago. 06, 2016. doi: 10.1002/uog.3966.

BLANCO, P.G. et al. Doppler ultrasound in canine pregnancy. Journal of Ultrasound in Medicine, v.27, p.1745-1750, 2008. Available from: $<$ http://www.jultrasoundmed.org/content/27/12/1745. long>. Accessed: Aug. 08, 2016. doi: 10.7863/jum.2008.27.12.1745. 
BLANCO, P.G. et al. Echocardiographic and Doppler assessment of maternal cardiovascular function in normal and abnormal canine pregnancies. Theriogenology, v.78, p.1235-1242, 2012. Available from: <http://www.theriojournal.com/article/S0093691X(12)00309-3/fulltext>. Accessed: Aug. 08, 2016. doi: 10.1016/j.theriogenology.2012.05.019.

BLANCO, P.G. et al. Ultrasonographic assessment of maternal cardiac function and peripheral circulation during normal gestation in dogs. Veterinary Journal, v.190, p.154-159, 2011. Available from: <http://www.theriojournal.com/article/S0093691X(12)00309-3/fulltext $>$. Accessed: Aug. 05, 2016. doi: http:// dx.doi.org/10.1016/j.theriogenology.2012.05.019.

BLANCO, P.G. et al. An experimental model to study resistance index and systolic/diastolic ratio of uterine arteries in adverse canine pregnancy outcome. Reproduction in Domestic Animals, v.44 p.164-166, 2009. Available from: <http://www.ncbi.nlm.nih.gov/ pubmed/19754559>. Accessed: Aug. 08, 2016. doi: 10.1111/j.14390531.2009.01369.x.

BLANCO, P.G. et al. Electrocardiographic changes in normal and abnormal canine pregnancy. Reproduction in Domestic Animals, v.47, p.252-256, 2012. Available from: <http://www.ncbi.nlm.nih.gov/ pubmed/21749484>. Accessed: Aug. 08, 2016. doi:10.1111/j.14390531.2011.01846.x.

BROOKS, V.L.; KEIL, L.C. Changes in the baroreflex during pregnancy in conscious dogs: heart rate and hormonal responses. Endocrinology, v.135, p.1894-1901, 1994. Available from: <http:// press.endocrine.org/doi/pdf/10.1210/endo.135.5.7956910>. Accessed: July 17, 2016. doi:10.1210/endo.135.5.7956910.

CHOONG, C.Y. et al. Preload dependence of doppler-derived indices of left ventricular diastolic function in humans. Journal of the American College of Cardiology, v.10, p.800-808, 1987. Available from: <http://content.onlinejacc.org/article.aspx?articleid=1112918>. Accessed: Aug. 08, 2016. doi: 10.1016/S0735-1097(87)80273-5.

DAVIS, L.E. et al. Vascular pressure-volume relationships in pregnant and estrogen-treated guinea pigs. American Journal of Physiology Regulatory, Integrative and Comparative Physiology, v. 257, n.5, p.1205-1211，1989. Available from: <http://ajpregu.physiology.org/ content/ajpregu/257/5/R1205.full.pdf $>$. Accessed: Aug. 08, 2016.

DESAI, D.K. et al. Echocardiographic assessment of cardiovascular hemodynamics in normal pregnancy. Obstetrics Gynecology, v.104, p.20-29. 2004. Available from: <http://www.ncbi.nlm.nih. gov/pubmed/15228996>. Accessed: Aug. 08, 2016. doi: 10.1097/01. AOG.0000128170.15161.1d.

DI SALVO, P. et al. Doppler evaluation of maternal and fetal vessels during normal gestation in the bitch. Research in Veterinary Science, v.81, p.382-388, 2006. Available from: <http://www. sciencedirect.com/science/article/pii/S0034528806000750>. Accessed: Aug. 09, 2016. doi: 10.1016/j.rvsc.2006.03.004.

DUVEKOT, J.J. et al. Early pregnancy changes in hemodynamics and volume homeostasis are consecutive adjustments triggered by a primary fall in systemic vascular tone. American Journal of Obstetrics and Gynecology, v.169, p.1382-1392, 1993. Available from: <http://www. sciencedirect.com/science/article/pii/0002937893904058>. Accessed: Aug. 08, 2016. doi: 10.1016/0002-9378(93)90405-8.

EGHBALI, M. et al. Molecular and functional signature of heart hypertrophy during pregnancy. Circulation Research, v.96, p.1208-1216, 2005. Available from: <http://circres.ahajournals. org/content/96/11/1208.full.pdf + html >. Accessed: Aug. 08, 2016. doi: 10.1161/01.RES.0000170652.71414.16.

FOK W.Y. et al. Left ventricular diastolic function during normal pregnancy: assessment by spectral tissue Doppler imaging. Ultrasound in Obstetrics \& Gynecology, v.28, p.789-793, 2006. Available from: $<$ http://onlinelibrary.wiley.com/doi/10.1002/uog.3849/full >. Accessed: Aug. 08, 2016. doi: 10.1002/uog.3849.

GELENS, H.C., IHLE, S.L. Failure to grow. Veterinary Clinics of North America: Small Animal Practice, v.29, p.989-1001,1999. Available from: $<$ http://www.sciencedirect.com/science/article/pii/S0195561699500867>. Accessed: Aug. 09, 2016. doi: 10.1016/S0195-5616(99)50086-7.

GILSON, G.J. et al. Systemic hemodynamics and oxygen transport during pregnancy in chronically instrumented, conscious rats. American Journal of Physiology, v.263, p.1911-1918, 1992. Available from: <http://ajpheart.physiology.org/content/263/6/H1911>. Accessed: Aug. 06, 2016.

GORDON, M.C. Maternal physiology in pregnancy. In: GABBE, S.G.et al. Obstetrics e normal and problem pregnancies. New York: Churchill Livingstone, 2002. p. 63-91.

KITTLESON, M.D. Primary myocardial disease. In: KITTELSON, M.D.; KIENLE, R.D. Small animal cardiovascular medicine. St. Louis: Mosby, 1998. p. 319-346.

KITZMAN, D.W. et al. Cardiovascular health study research group. Importance of heart failure with preserved systolic function in patients $\geq 65$ years of age. CHS Research Group. Cardiovascular Health Study. American Journal of Cardiology, v.87, p.413-419, 2001. Available from: $<$ http://www.ajconline.org/article/S0002-9149(00)01393-X/abstract> . Accessed: Aug. 09, 2016. doi: 10.1016/S0002-9149(00)01393-X.

LEWIS G.; DRIFE, J. Confidential enquiry into maternal and child health: why mothers die. Archives of Disease in Childhood, v.88, p.1034-1037, 2003. Available from: <http://adc.bmj.com/ content/88/12/1034.short.doi:10.1136/adc.88.12.1034>. Accessed: Aug. 09, 2016. doi: 10.1136/adc.88.12.1034.

LIN, S. et al. Uterine artery Doppler velocimetry in relation to trophoblast migration into the myometrium of the placental bed. Obstetrics and Gynaecology, v.8, n.5, p.760-765, 1995. Available from: $<$ http://journals. lww.com/greenjournal/toc/1995/05000>. Accessed: Aug. 09, 2016. doi: 10.1016/0029-7844(95)00020-R10.1016/0029-7844(95)00020-R.

LONGO, L.D. Maternal blood volume and cardiac output duringpregnancy: a hypothesis of endocrinologic control. American Journal of Physiology - Regulatory, Integrative and Comparative Physiology, v.245, n.5, p.720-729, 1983. Available from: <http://ajpregu.physiology.org/content/ ajpregu/245/5/R720.full.pdf $>$. Accessed: Aug. 09, 2016.

MORAN, A.M. et al. Adaptive mechanisms of left ventricular diastolic function to the physiologic load of pregnancy. Clinical Cardiology, v.25, p.124-131, 2002. Available from: <http://onlinelibrary.wiley. com/doi/10.1002/clc.4960250308/epdf>. Accessed: Aug. 09, 2016. doi: $10.1002 /$ clc.4960250308.

MÜNNICH, A.; KÜCHENMEISTER, U. Dystocia in numbers Evidence-based parameters for intervention in the dog: causes for dystocia and treatment recommendations. Reproduction in Domestic Animals, v.44, p.141-147, 2009. Available from: <http://onlinelibrary. wiley.com/doi/10.1111/j.1439-0531.2009.01405.x/pdf >. Accessed: Aug. 09, 2016. doi: 10.1111/j.1439-0531.2009.01405.x. 
NAGUEH, S.F. et al. Doppler tissue imaging: a non-invasive technique for evaluation of left ventricular relaxation and estimation of filling pressures. Journal of the American College of Cardiology, v.30, p.1527-1533, 1997. Available from: <http://content.onlinejacc. org/article.aspx?articleid=1124262>. Accessed: Aug. 09, 2016. doi: 10.1016/S0735-1097(97)00344-6.

NAUTRUP, C.P. Doppler ultrasonography of canine maternal and fetal arteries during normal gestation. Journal of Reproduction and Fertility, v.112, p.301-314, 1998. Available from: <http:// www.reproduction-online.org/content/112/2/301.full.pdf + html $>$. Accessed: Aug. 09, 2016. doi: 10.1530/jrf.0.1120301.

NOVELLI, G.P. et al. Left ventricular concentric geometry as a risk factor in gestational hypertension. Hypertension, v.41, p.469-475, 2003. Available from: <http://hyper.ahajournals.org/ content/41/3/469.full.pdf + html $>$. Accessed: Aug. 09, 2016. doi: 10.1161/01.HYP.0000058001.67791.0A.

OLSSON,K. etal.Change ofdiurnalheartratepatternsduring pregnancy andlactationindogs(Canisfamiliaris).Acta VeterinariaScandinavica, v.44, p.105, 2003. Available from: $<$ http://actavetscand.biomedcentral. com/articles/10.1186/1751-0147-44-105>. Accessed: Aug. 09, 2016. doi: 10.1186/1751-0147-44-105.

PHIPPARD, A.F. et al. Circulatory adaptation to pregnancy- serial studies of haemodynamics, blood volume, renine and aldosterone in the baboon (Papio hamadryas). Journal of Hypertension, v.4, p.773-779, 1986. Available from: <http://journals.lww.com/ jhypertension/toc/1986/12000>. Accessed: Aug. 09, 2016. doi: 10.1097/00004872-198612000-00013.

PRESTES, N.C.; LANDIM-ALVARENGA, F.C. Obstetrícia veterinária. Rio de Janeiro: Guanabara Koogan, 2006. 241p.

SARAFANA. S. et al. Aspects of pregnancy immunology. Acta Medica Portuguesa, v.20, p.355-358, 2007. Available from: $<$ http:// www.actamedicaportuguesa.com/revista/index.php/amp/article/ view/865/539>. Accessed: Aug. 09, 2016

SOHN, D.W. et al. Assessment of mitral annulus velocity by doppler tissue imaging in the evaluation of left ventricular diastolic function. Journal of the American College of Cardiology, v.30, p.474-480, 1997. Available from: $\quad<\mathrm{http}$ //content.onlinejacc.org/article.aspx?articleid=1124131>. Accessed: Aug. 09, 2016. doi: 10.1016/S0735-1097(97)88335-0.
SPOTSWOOD, T.C. et al. Changes in echocardiographic variables of left ventricular size and function in a model of canine normovolemicanemia. Veterinary Radiology and Ultrasound, v.47, p.358-365, 2006. Available from: <http://onlinelibrary.wiley.com/ doi/10.1111/j.1740-8261.2006.00154.x/full>. Accessed: Aug. 09, 2016. doi: $10.1111 /$ j.1740-8261.2006.00154.x

TILLEY, L.P.; GOODWIN, J.K. Manual of canine and feline cardiology. Philadelphia: Saunders, 2002. p.464.

THOMAS, W.P. Recommendations for standards in transthoracic two-dimensional echocardiography in the dog and cat.Journal of Veterinary Internal Medicine, v.7, p.247252, 1993. Available from: <http://onlinelibrary.wiley.com/ doi/10.1111/j.1939-1676.1993.tb01015.x>. Accessed: Aug. 09, 2016. doi: 10.1111/j.1939-1676.1993.tb01015.x.

TONIOLLO G.H.; VICENTE W. R.R. Manual de obstetrícia veterinária. São Paulo: Livraria Varela, 1993. 124p.

VALENSISE, H. et al. Maternal cardiac systolic and diastolic function: relationship with uteroplacental resistances. A Doppler and echocardiographic longitudinal study. Ultrasound in Obstetrical and Gynecology, v.15, p.487-497, 2000. Available from: <http:// onlinelibrary.wiley.com/doi/10.1046/j.1469-0705.2000.00135.x/ full>. Accessed: Aug. 09, 2016. doi: 10.1046/j.14690705.2000.00135.x

WILLIAMS, J.G. et al. Role of nitric oxide in the coupling of myocardial oxygen consumption and coronary vascular dynamics during pregnancy in the dog.American Journal of Physiology: Heart and Circulatory Physiology, v.293, p.2479-2486, 2007. Available from: <http://ajpheart. physiology.org/content/293/4/H2479>. Accessed: Aug. 09, 2016. doi: 10.1152/ajpheart.00036.2006.

YAMAMOTO, K. Analysis of left ventricular diastolic function. Heart, v.75, p.27-35, 1996. Available from: <http:// www.ncbi.nlm.nih.gov/pmc/articles/PMC484403>. Accessed: Aug. 09, 2016.

ZILE, M.R.; BRUTSAERT, D.L. New concepts in diastolic dysfunction and diastolic heart failure: Part II: causal mechanisms and treatment. Circulation, v.105, p.1503-1508, 2002. Available from: <http://circ. ahajournals.org/content/105/12/1503.short>. Accessed: Aug. 09, 2016. doi: $10.1161 / \mathrm{hc} 1202.105290$. 